\title{
ANALYSIS OF THE INFLUENCE OF HEALTH EDUCATION TO IMPROVE MOTHER'S KNOWLEDGE IN PREVENTING STUNTING IN MASOLAKA RAYA SUB-DISTRICT, BOMBANA DISTRICT
}

\author{
Yulfiah Suleman ${ }^{1}$, Tasnim Tasnim ${ }^{2}$, Herianto Wahab ${ }^{3}$ \\ ${ }^{1,2,3}$ Master of Public Health Study Program, Universitas Mandala Waluya \\ Kendari, Southeast Sulawesi Province, Indonesia
}

Corresponding Author: Yulfiah Suleman

Email : syulfiah@gmail.com

\section{Abstract}

Background:Data showed that the Bombana Health Office stated that the details of stunting cases in 19 Districts were highest in Central Kabaena District with 160 cases, Central Kabaena 120 cases, Masolaka Raya 57 cases, North Poleang 54 cases, and the lowest was Mataoleo District. The purpose of this research isto analyze the effect of health education in efforts to prevent stunting through changes in knowledge, attitudes and actions of mothers of children under five in Masolaka Raya District, Bombana Regency.

Methods:The research used a quasi-experimental study with a non-equivalent control group design. The population in this study were 159 people. The sample size was 114 people. The data were processed using the Wilcoxon signed rank test and the Kruskal Wallis H. test.

Results:Based on the test with the Wilcoxon signed rank test, the significance value shows the value of $\mathrm{p}$-value $=0.000<\alpha=0.05$ for all health education methods to increase the knowledge of mothers under five in preventing stunting in Masolaka Raya District, Bombana Regency.

Conclusion:There is an effect of health education with the lecture method, lecture method and leaflet, lecture method and video on increasing the knowledge of mothers under five in preventing stunting in Masolaka Raya Sub-District, Bombana Regency.

Key words: Lecture,Method, Leaflet, Video, Knowledge, Stunting 


\section{INTRODUCTION}

The problem of stunting is one of the problems faced in the world, especially in poor and developing countries (1). Stunting is a problem because it is associated with an increased risk of illness and death, suboptimal brain development so that motor development is stunted and mental growth retarded(2).

Bappenas (2018) shows that "stunting" in toddlers is increasing. With this condition, attention to the problem of multiple nutrition needs to be increased because it is an important factor in preventing nutritional problems and maintaining a good nutritional status(3). Riskesdas 2018, shows an improvement in the proportion of stunting from $37.2 \%$ in 2013 to $30.8 \%$, which means an improvement in the nutritional status of children in Indonesia. However, the stunting rate is still considered high when compared to WHO standards, which is less than 20\%(4).

Efforts to prevent stunting are fulfilling the nutritional needs of mothers, both macro and micro and giving exclusive breastfeeding to babies until the age of 6 (six) months (Sutarto, Mayasari, \& Indriyani, 2018). The obstacles faced today are that there are still many pregnant women who do not realize the importance of paying attention to the nutrients consumed during pregnancy and how to prepare themselves to breastfeed their babies immediately after birth so that they do not suffer from malnutrition.

The results of Riskesdas (2018) show that the incidence of stunting in Indonesia in 2007 for the short and very short category was $36.8 \%$ in 2013 the short and very short category was $37.2 \%$ and in 2018 for the short and very short category it was $30.8 \%$. Although the data shows a decrease in the incidence of stunting, this value is not yet in accordance with the National target for the incidence of stunting, which is $20 \%$ (5).

Data from the Southeast Sulawesi Provincial Health Office shows that in 2019 the stunting rate for children under five aged
0-59 months exceeded the number 2,920 cases, with details of the highest cases being in North Kolaka Regency with 577 cases, the second place was Bombana Regency with 262 cases, Kolaka Regency 255. cases, 207 cases and the lowest was in Wakatobi District (6).

Health education is the activity of acquiring new knowledge, changing attitudes, adopting new behaviors or implementing new skills (7). Health education is an effort or activity carried out to assist individuals, families and communities in improving their behavior to achieve optimal health(8). The goal of health education is to help individuals, families or communities to reach an optimal level(9).

Education is a part of health education activities. Health education is defined as a learning process carried out to individuals, families, groups and communities with the aim of changing unhealthy behavior to healthier patterns. The health education process involves several components, including using teaching and learning strategies, maintaining decisions to make action / behavior changes, and health education also focusing on changing behavior to improve their health status(10).So it needs community counseling and empowerment, then it needs cross-sector participation and involvement as well as parties who can set an example in society(11).

Mothers with good nutritional knowledge are likely to provide adequate nutrition to their babies. If a mother has good knowledge, the mother will try to fulfill her nutritional needs as well as her baby's knowledge of pregnant women about nutrition will influence decision making and will also affect the mother's behavior(12). Based on the background description above, it shows that the incidence of stunting is still a serious problem that needs further treatment and prevention so that it can achieve the national target. 


\section{METHOD}

This type of research uses a quasiexperimental (all research) research design with a non-equivalent control group design. This research was conducted in the Masolaka Raya Subdistrict, Bombana Regency. The population in this study were all mothers of toddlers who have children under five in the Masolaka Raya sub-district, totaling 159 people consisting of 37 Masolaka Village, 38 Masolaka Timur Village, 50 Batu Lamburi Village, and 34 children under West Masolaka Village. The sample in this study was divided into 3 parts according to research interests with 38 samples per group each. Namely the group that received the lecture method intervention, the group that received the lecture and leaflet intervention, and the group that received the lecture and video intervention. The statistical tests used in this research are: Test Wilcoxon signed rank test and Kruskal Wallis H. test.

\section{RESULTS}

Table 1 shows that the average value of the respondent's knowledge before being given health education through the lecture method was 54.47 with a standard deviation of 8.605, while after being given health education through the lecture method there was an increase in knowledge with an average value of 74.47 with a standard deviation of 14.084 .

Table 2 shows that the average value of the respondent's knowledge before being given health education through the lecture $\&$ leaflet method was 55.53 with a standard deviation of 7.952 while after being given health education through the lecture and leaflet method there was an increase in knowledge with an average value of 76.32 with a standard deviation of 14,031.

Table 3 shows that the average value of the respondent's knowledge before being given health education through the lecture \& video method is 55.26 with a standard deviation of 7.965 , while after being given health education through the lecture and video methods there is an increase in knowledge with an average value of 81.58 with standard deviation 8,861 .

Table 4 shows that based on the test results with the Wilcoxon signed rank test, the significant value shows the value of $\mathrm{p}$ value $=0.000<\alpha=0.05$, it can be concluded that there is an effect of the lecture method on increasing the knowledge of mothers under five in preventing stunting in Masolaka Raya District, Bombana Regency.

Table 5 shows that based on the test results with the Wilcoxon signed rank test, the significant value shows the value of $\mathrm{p}$ value $=0.000<\alpha=0.05$, it can be concluded that there is an effect of lecture and leaflet methods on increasing knowledge of mothers under five in preventing stunting in Masolaka Raya District, Bombana Regency.

Table 6 shows that based on the test results with the Wilcoxon signed rank test, the significant value shows the value of $\mathrm{p}$ value $=0.000<\alpha=0.05$, it can be concluded that there is an effect of lecture and video methods on increasing the knowledge of mothers under five in preventing stunting in Masolaka Raya District, Bombana Regency.

Table 1

Distribution of Respondents' Knowledge Before and After Giving Health Education through Lecture Method to Mother Toddlers in Masaloka Raya Sub-District

\begin{tabular}{l|c|c|c}
\hline \multicolumn{1}{c|}{ Knowledge } & $\mathrm{n}$ & Mean & Standard Deviation \\
\hline Before & 38 & 54.47 & 8,605 \\
\hline After & 38 & 74.47 & 14,084 \\
\hline
\end{tabular}

Source: Primary Data 2020 
Table 2

Distribution of Respondents' Knowledge Before and After Giving Health Education through Lecture Methods \& Leaflets for Mother Toddlers in Masaloka Raya Sub- District

\begin{tabular}{l|c|c|c}
\hline \multicolumn{1}{c|}{ Knowledge } & $\mathrm{n}$ & Mean & Standard Deviation \\
\hline Before & 38 & 55.53 & 7,952 \\
\hline After & 38 & 76.32 & 14,031
\end{tabular}

Source: Primary Data 2020

Table 3

Distribution of Respondents' Knowledge Before and After Giving Health Education through Lecture \& Video Methods for Mother Toddlers in Masaloka Raya Sub-District

\begin{tabular}{l|c|c|c}
\hline \multicolumn{1}{c|}{ Knowledge } & $\mathrm{n}$ & Mean & Standard Deviation \\
\hline Before & 38 & 55.26 & 7,965 \\
\hline After & 38 & 81.58 & 8,861 \\
\hline
\end{tabular}

Source: Primary Data 2020

Table 4

Analysis of the Effect of the Lecture Method on Knowledge of Prevention of Stunting in Toddlers in Masaloka Raya Sub-District, Bombana Regency

\begin{tabular}{c|c|c|c|c|c}
\hline \multicolumn{2}{c|}{ Prior Knowledge } & \multicolumn{2}{|c|}{ Knowledge After } & & \\
\cline { 1 - 4 } Less & Enough & Less & Enough & n & Statistic test \\
\hline 19 & 19 & 4 & 34 & 38 & P Value $=0.000$ \\
\hline
\end{tabular}

Source: Primary Data 2020

Table 5

Analysis of the Effect of Lecture and Leaflet Methods on Knowledge of Prevention of Stunting in Toddlers in Masaloka Raya Sub-District Bombana Regency

\begin{tabular}{c|c|c|c|c|c}
\hline \multicolumn{2}{c|}{ Prior Knowledge } & \multicolumn{2}{|c|}{ Knowledge After } & \multirow{2}{*}{ Statistic test } & \\
\cline { 1 - 4 } Less & Enough & Less & Enough & & \\
\hline 14 & 24 & 0 & 38 & 38 & P Value $=0.000$ \\
\hline
\end{tabular}

Source: Primary Data 2020

\section{DISCUSSION}

The Effect of the Lecture Method on the Knowledge of Toddler Mother in Stunting Prevention in Masaloka Raya SubDistrict, Bombana Regency

Before being given the treatment of the health education method in the form of a lecture method, the average results obtained were that the respondents had insufficient knowledge of 19 and the respondents had sufficient knowledge of 19. For respondents with sufficient knowledge the values obtained were not too far from the standard value range. After being given health education in the form of a lecture method, 
the results of the respondent's knowledge with a score of less than 4 respondents and a sufficient value increased to 34 people. This shows that the health education method using the lecture method is able to have an effect so that respondents' knowledge about stunting prevention can increase even though there are still respondents who have not increased their knowledge.

The result of the test with the Wilcoxon signed rank test, the significant value shows the value of $p$-value $=0.000<\alpha$ $=0.05$, it can be concluded that there is an effect of the lecture method on increasing the knowledge of mothers under five in preventing stunting in Masolaka Raya District, Bombana Regency. The results of this study are in line with research conducted by Masyudi (2020). The results obtained in this study are that the use of media in counseling can increase the knowledge of mothers under five as evidenced by a $\mathrm{p}$-value of 0,000 .

The weakness of the lecture media is that most of the pregnant women did not focus when the research began because there were no visible images or examples in the form of photos, so mothers under five were unable to absorb what was conveyed by researchers, because flipchart media was more effective in delivering material other than explained by the researcher, the respondents were able to see directly the photos or examples on the flipchart.

\section{The Influence of Lecture \& Leaflet Methods on Maternal Toddler Knowledge in Stunting Prevention in Masaloka Raya Sub-District, Bombana Regency}

The media is one of the tools that greatly influences an extension because it can help and facilitate the delivery of material and aids to demonstrate something the instructor wants to convey. (6).

The results showed that before the health education methods were given in the form of lectures and leaflets of the respondent's knowledge of 14 people and 24 people who were sufficient, the average mother was not able to explain the efforts to prevent stunting in toddlers, and some were able to explain but still some of the answers are wrong. However, after being given health education methods in the form of lecture methods and leaflets, it was found that none of the respondents got less value and all respondents increased to sufficient knowledge.

The result of the test with the Wilcoxon signed rank test, the significant value shows the value of $p$-value $=0.000<\alpha$ $=0.05$, it can be concluded that there is an effect of lecture and leaflet methods on increasing the knowledge of mothers under five in preventing stunting in Masolaka Raya District, Bombana Regency.

$$
\text { According to(7)Delivering }
$$
information through flipchart media or flipchart media will get maximum results and as expected, because this media has two benefits besides being able to be heard and being able to observe what is in front of the mother, although not directly. In the teaching methodology, there are two most prominent aspects, namely the teaching method and teaching media as teaching aids. If counseling is carried out using the media, mothers are more active in following counseling, because the media can create interest and attract the attention of mothers which can foster motivation and interest of respondents, so that mothers understand and understand the purpose of doing counseling.

\section{The Effect of Lecture \& Video Methods on Maternal Toddler Knowledge in Stunting Prevention in Masaloka Raya Sub-district, Bombana Regency}

Health promotion media is one of the means or efforts that can be used to display messages or health information to be conveyed to mothers under toddlers so that they can increase their knowledge which in turn is expected to change their behavior towards positive or supportive health.

The results showed that in 38 respondents, it was found that 12 respondents had insufficient knowledge and 
26 people had sufficient knowledge. Respondents 'knowledge of efforts to prevent stunting was measured prior to the implementation of health education methods to measure the extent of respondents' knowledge about stunting prevention efforts. Although the results of the measurement before being given the health education method, there were 26 respondents with sufficient knowledge, but the average results of the respondents were not far from the predetermined standard values so that there are still many efforts to prevent stunting that must be known by mothers of toddlers in terms of preventing stunting.

After being given treatment in the form of health education methods by means of lectures and videos, it is known that there are no more respondents who have less knowledge and all respondents' knowledge is sufficient. The results of this study are able to have an influence on the respondent's knowledge because in addition to giving lectures but also given to respondents about the display of videos which are expected to attract the attention of respondents so that the meaning of carrying out health education will be easily conveyed to respondents.

The results of the test with the Wilcoxon signed rank test with the significant value showed the value of pvalue $=0.000<\alpha=0.05$, it can be concluded that there is an effect of lecture and video methods on increasing the knowledge of mothers under five in preventing stunting in Masolaka Raya District, Bombana Regency. This is in accordance with the research conducted by (8), which suggests that there is an effect of health education with the video method, because the message conveyed can be received well. This means that the success of counseling can be influenced by the media because the media can influence knowledge, attitudes and emotions. The use of appropriate extension methods and extension media can increase efficiency and effectiveness in the implementation of health education in the community, urgent motivation will result in fast behavior, but these changes will not last long because behavior changes that occur are not or have not been based on one's own awareness.(9).

\section{The Most Effective Educational Method for Maternal Toddler Knowledge in Stunting Prevention in Masaloka Raya Sub-district, Bombana Regency}

The health education method used in this research is the lecture method, the lecture method with leaflets and the lecture method with videos. All of these health education methods were tested on mothers of children under five to increase respondents' knowledge of stunting prevention efforts. The results of the research conducted show thatHealth education methods using lectures and videos are more effective in increasing the knowledge of mothers under five in preventing stunting compared to lecture methods or lecture methods using leaflets. This is evidenced by the mean rank value of the lecture and video methods with the highest value, namely 72.88 .

On the results of research that researchers have tested using the SPSs test Kruskal Wallis $\mathrm{H}$ The results show that among the three media, the three of them can increase the knowledge of mothers under five, but the one that is more dominant in increasing knowledge in this study is the lecture method with video. Mother's knowledge can help mothers to give child feeding. Therefore, their knowledge affects significantly to child nutritional status (10).

\section{CONCLUSION}

There is an effect of health education with the lecture method, lecture method and leaflet, lecture method and video on increasing the knowledge of mothers under five in preventing stunting in Masolaka Raya District, Bombana Regency. It is also known that the health education method using lectures and videos is more effective in increasing the knowledge of mothers under 
five in preventing stunting compared to the lecture method or the lecture method with leaflets. So it is necessary to consider the use of lecture and video methods so that in carrying out health education, respondents can quickly understand and the messages conveyed will be easily understood by the mothers of toddlers.

\section{REFERENCES}

1. World Health Organization \& UNICEF. Progress on sanitation and drinking-water: World Health Organization; 2013.

2. Mitra M. Stunting problems and interventions to prevent stunting (a Literature Review). Jurnal Kesehatan Komunitas. 2015;2(6):254-61.

3. Park LP, Chu VH, Peterson G, Skoutelis A, Lejko-Zupa T, Bouza E, et al. Validated risk score for predicting 6-month mortality in infective endocarditis. Journal of the American Heart Association. 2016;5(4):e003016.

4. Lestari W, Kristiana L, Paramita A. Stunting: Study about social construction in village and urban communities relating to nutrition and pattern of nursury for under-five years old children in Jember District. Aspirasi: Jurnal Masalah-masalah Sosial. 2018;9(1):17-33 (Indonesia).

5. Satriawan E. Increasing in national strategi in Stunting prevention in 2018-2024. Jakata: Tim Nasional Percepatan Penanggulangan Kemiskinan (TNP2K). 2018 (Indonesia).

6. Notoadmodjo S. Introduction of Health and Behaviour Sciences. Andi Offset Yogyakarta. 2003.

7. Utami ASF, Baiti N. The effect of social media to behaviour in cyberbullying in teenagers. Cakrawala-Jurnal Humaniora. 2018;18(2):257-62 (Indonesia).
8. Afrianto D. The effect of heapth promotion to paprica farmers' knowledge, attitude and practice in Kumbo-Pasuruan Village relating to personal protection equipment of pesticade effect in 2014. 2014.

9. Siahaan VR, Pangestu JF, Fitriyani M. Effectivity of audio visual methods users to increase the teenagers' knowledge about sexs before marriage. Jurnal Kebidanan Malahayati. 2020;6(1):32-6 (Indonesia).

10. Tasnim, T., Mwanri L, Dasvarma, G. Mother's child feeding knowledge and practices associated with underweight in children under-five years: A study from Rural Konawe, Indonesia. Public Health of Indonesia. 2018;4(1):9-18. 